\title{
Seroprevalence of brucellosis in animals and human populations in the western mountains region in Libya, December 2006-January 2008
}

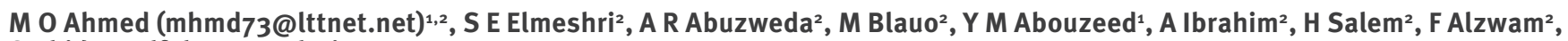
S Abid ${ }^{2}$, A Elfahem², A Elrais ${ }^{2}$

1. Department of Microbiology and Parasitology, Faculty of Veterinary Medicine, Al Fateh University, Tripoli, Libya

2. Department of Microbiology, Biotechnology Research Centre, Tripoli, Libya

Ahmed MO, Elmeshri SE, Abuzweda AR, Blauo M, Abouzeed YM, Ibrahim A, Salem H, Alzwam F, Abid S, Elfahem A, Elrais A. Seroprevalence of brucellosis in animals and human populations in the western mountains region in Libya, December 2006-January 2008. Euro Surveill. 2010;15(30):pii=19625. Available online: http:// www.eurosurveillance.org/ViewArticle.aspx?Articleld $=19625$

Brucellosis is a global zoonotic disease, endemic in North African countries and around the Mediterranean. A prospective study of Brucella seroprevalence was conducted in north-western Libya (western mountains region). Blood samples collected over 13 months in the period December 2006 to January 2008 from 561 animals (goats, sheep, cattle and camels) and 546 human volunteers were tested for Brucella using the Rose Bengal test, tube agglutination test and ELISA assays. Amongst livestock, $31 \%$ of goats and $42 \%$ of cattle were seropositive. Human samples showed a high seropositivity of $40 \%$, with $95(43 \%)$ of the 221 positive samples positive for IgM, indicating active or recent infection. Control measures are needed to reduce this high prevalence of brucellosis in Libya.

\section{Introduction}

Brucellosis is a global zoonotic disease associated with significant morbidity that can lead to increased rates of spontaneous abortions in livestock and also in humans [1-6]. The disease is widely distributed throughout the developing world, considered to be a serious problem in at least 86 countries [7]. Brucellosis is a severe zoonosis in North African countries [8] and the Near East $[9,10]$ causing economic and livestock losses and affecting industrial production $[3,11]$. In these regions Brucella melitensis, the predominant species in goats and sheep, has spread to other animals such as cattle and camels. B. melitensis is also the dominant type in humans [9]. Consumption of unpasteurised milk and milk products from cows, small ruminants or camels is considered to be the main route of infection as well as an occupational hazard [12]. In the North African region, as in sub-Saharan countries, social and economic factors play a major role in the spread of brucellosis [13]. Libya is considered to be endemic for brucellosis [2], although little information is available; previous studies are limited to food-producing animals such as cattle and goats [14-16] and reports of human brucellosis in Libya are limited to a few cases $[9,17]$.
We investigated the seroprevalence of brucellosis in humans and several livestock species around eight cities in the Yafran municipality, Al Jabal al Gharbi district (Western mountains region), north-west Libya. This region is $9,310 \mathrm{~km} 2$, with a population of 153,000 , and dependent on livestock production, mainly goats (750,000 sheep and goats and around 8,000 camels). The Yafran is well-known for its rural culture and traditional lifestyle, where different livestock species are kept together and people live in close proximity to their livestock. Brucellosis is the likely cause of economic losses for owners and companies through abortions in pregnant animals especially in goats.

\section{Methods and materials}

Study design

We investigated the seroprevalence of Brucella in the Yafran, both in livestock and in humans, from samples collected over a period of 13 months from December 2006 to January 2008. A total of 561 blood samples were collected from different animals (a convenience sample of 340 goats, 188 sheep, 19 cattle, 14 camels). Human blood samples were also collected from 546 selected individuals ( 332 male and 214 female) from the populations in the area surrounding the farms, who worked and/or had contact with the studied animals. Both human and animal populations are widely dispersed in this large area in Libya, and due to the socioeconomic factors of the involved region a few small towns could not be included in this study.

\section{Diagnostic methods}

Animal and human samples were processed in various laboratories in Libya, as described $[18,19]$ using the Rose Bengal test and ELISA for the detection of Brucella in serum (DRG Brucella IgM-ELISA and Brucella IgG ELISA). Whole blood samples of $5 \mathrm{ml}$ were collected aseptically. Serum was stored at $2-8{ }^{\circ} \mathrm{C}$ until testing could be performed. Statistical analysis was performed using the two-proportion z-test. Lifestyle data on milk 
consumption and animal contact were collected using a simple questionnaire.

\section{Results and discussion}

The prevalence of Brucella in different livestock species is summarised in Table 1. Rates of seropositivity were 1.6 times higher $(p=0.05$,$) in goats (31 \%)$ than in sheep (24\%). A local serological survey at the Al Jabal al Gharbi University in the western mountains region in 1997 found that $8.5 \%$ of sheep, $28.4 \%$ of goats, and $3.5 \%$ of camels were positive for brucellosis [20]. Our data indicate a substantial increase over the past ten years, with $24 \%$ of sheep, $31 \%$ of goats and $14 \%$ of camels testing positive for Brucella in our study. The increased prevalence in different animal species may be attributable to husbandry methods. Previous research has shown that controlling this disease in goats and sheep can be effective in reducing infection in other livestock [11]. The role of goats in perpetuating brucellosis and in disseminating the disease among humans has also been highlighted [4].

The overall prevalence of Brucella seropositivity among humans in the Yafran municipality was $40 \%$, with Jado (47\%) and Yifrin (46\%) having the highest proportion of brucellosis brucellosis-positive people (Table 2). The prevalence of IgG and IgM antibodies in seropositive individuals was $57 \%(126 / 221)$ and $43 \%(95 / 221)$, respectively, suggesting that a substantial proportion of the population in this region were actively or recently infected. This compares with $8 \%$ seropositivity in Egypt [11] where control measures have been introduced.

We observed that significantly more seropositive humans had a history of raw milk consumption than had direct contact with livestock $(71 \%$ and $58 \%$, respectively, p<0.02). Similarly, a study of female brucellosis patients in Egypt found that more than $87 \%$ had a history of raw milk consumption [5], which has been identified as a risk factor also by other authors [10,12]. We noticed that seropositivity in the Yafran municipality, Libya, was higher among males than females, with $66 \%$ of samples from males and $34 \%$ of samples from females positive for Brucella infection in our study. This could be explained by the fact that in the culture and tradition of that region raw milk is consumed more frequently by men.

Effective eradication campaigns in the European Union have significantly reduced the incidence of brucellosis, with many countries being given brucellosis-free status [2]. Programmes and control measures have been undertaken in many countries in North Africa and the

\section{TABLE 1}

Prevalence of Brucella in domestic animal species assayed by the Rose Bengal test, Libya, December 2006-January 2008

\begin{tabular}{|l|c|c|c|}
\hline Animal species & Animals tested & Seropositive animals & 104 \\
\hline Goats & 340 & 45 & $31 \%$ \\
\hline Sheep & 188 & 8 & $24 \%$ \\
\hline Cattle & 19 & 2 & $\mathbf{1 0}$ \\
\hline Camel & 14 & $\mathbf{1 5 9}$ & $\mathbf{2 8 \%}$ \\
\hline Total & $\mathbf{5 6 1}$ & & \\
\hline
\end{tabular}

All animals were apparently healthy at sampling; those with a history of any recent disease or vaccination were excluded.

\section{TABLE 2}

Brucella prevalence in humans, immunoglobulin analysis, and possible risk factors among seropositive volunteers from eight cities in the Yafran municipality, Libya, December 2006-January 2008

\begin{tabular}{|c|c|c|c|c|c|c|}
\hline \multirow[b]{2}{*}{ Locality } & \multirow{2}{*}{$\begin{array}{c}\text { Number of } \\
\text { samples } \\
\mathbf{n}\end{array}$} & \multirow[b]{2}{*}{$\begin{array}{c}\text { Positive samples } \\
\text { n (\%) }\end{array}$} & \multicolumn{4}{|c|}{ Analysis of Brucella-positive individuals } \\
\hline & & & $\begin{array}{c}\text { Drinking of raw milk } \\
\mathrm{n}(\%)\end{array}$ & $\begin{array}{l}\text { Direct contact with animals } \\
\qquad \mathbf{n}(\%)\end{array}$ & $\begin{array}{c}\text { IgG-positive } \\
\text { n }\end{array}$ & $\begin{array}{c}\text { IgM-positive } \\
\mathrm{n}\end{array}$ \\
\hline Zentan & 128 & $48(38)$ & $40(83)$ & $35(73)$ & 34 & 22 \\
\hline Jado & 196 & $93(47)$ & $61(66)$ & $52(56)$ & 44 & 36 \\
\hline Rujban & 29 & $11(38)$ & $8(73)$ & $6(55)$ & 8 & 4 \\
\hline Rehibat & 50 & $15(30)$ & $11(73)$ & $7(47)$ & 8 & 7 \\
\hline Qasr Alhaj & 12 & $4(33)$ & $3(75)$ & $2(50)$ & 1 & 3 \\
\hline Chkoke & 15 & $2(13)$ & $2(100)$ & $2(100)$ & 1 & 1 \\
\hline Morgan & 32 & $9(28)$ & $6(67)$ & $4(44)$ & 6 & 4 \\
\hline Yifrin & 84 & $39(46)$ & $25(64)$ & $20(51)$ & 24 & 18 \\
\hline Total & 546 & $221(40)$ & $156(71)$ & $128(58)$ & 126 & 95 \\
\hline
\end{tabular}


Near East (e.g. Egypt and Kuwait) $[11,21,22]$. However, underreporting and underdiagnosis of other food-borne pathogens is a problem around the Mediterranean [23], particularly in North African countries, where communication with local authorities is problematic and most of the available information is unpublished or limited to seminars and workshops [9]. The high prevalence of Brucella seropositivity in the Yafran municipality in Libya might suggests that the size of the problem has been underestimated by the authorities and that action needs to be taken to control brucellosis in this region.

\section{Conclusion}

We conclude that in the north-western region of Libya, Brucellosis seroprevalence is high in animals and human populations. Our data highlights the need for further research, including the isolation and characterisation of the causative agents, reliable epidemiological studies and the need to implement a transparency policy and effective control measures in Libya.

\section{Acknowledgements}

The authors are grateful to the study participants and staff from the Yafran region for their contributions to this study. This work was funded by the Biotechnology Research Centre, Tripoli, Libya.

\section{References}

1. Boschiroli ML, Foulongne V, O'Callaghan D. Brucellosis: A worldwide zoonosis. Curr Opin Microbiol. 2001;4(1):58-64.

2. Pappas G, Papadimitriou P, Akritidis N, Christou L, Tsianos EV. The new global map of human brucellosis. Lancet Infect Dis. 2006;6(2):91-9.

3. Corbel MJ. Brucellosis: An overview. Emerg Infect Dis. 1997;3(2):213-21.

4. Banai M. Control of small ruminant brucellosis by use of Brucella melitensis rev.1 vaccine: Laboratory aspects and field observations. Vet Microbiol. 2002;90(1-4):497-519.

5. Sabah AA, Aly AM, Tawab AH, Arafa WA. Brucellosis in Egyptian female patients. J Egypt Soc Parasitol. 2008;38(2):671-8.

6. Corbel MJ, Food and Agriculture Organization of the United Nations, World Health Organization, World Organisation for Animal Health. Brucellosis in humans and animals. Geneva: World Health Organization; 2006.

7. World Health Organization, Office of World Health Reporting. The world health report 1996: Fighting disease, fostering development: Executive summary. Geneva: World Health Organization; 1996

8. Aggad H, Boukraa L. Prevalence of bovine and human brucellosis in western Algeria: Comparison of screening tests. East Mediterr Health J. 2006;12(1-2):119-28.

9. Refai M. Incidence and control of brucellosis in the near east region. Vet Microbiol. 2002;90(1-4):81-110.

10. Jennings GJ, Hajjeh RA, Girgis FY, Fadeel MA, Maksoud MA, Wasfy MO, et al. Brucellosis as a cause of acute febrile illness in Egypt. Trans R Soc Trop Med Hyg. 2007;101(7):707-13.

11. Samaha H, Al-Rowaily M, Khoudair RM, Ashour HM. Multicenter study of brucellosis in Egypt. Emerg Infect Dis. 2008;14(12):1916-8.

12. Almuneef MA, Memish ZA, Balkhy HH, Alotaibi B, Algoda S, Abbas $M$, et al. Importance of screening household members of acute brucellosis cases in endemic areas. Epidemiol Infect. 2004;132(3):533-40.

13. Makita K, Fèvre EM, Waiswa C, Kaboyo W, De Clare Bronsvoort BM, Eisler MC, et al. Human brucellosis in urban and peri-urban areas of Kampala, Uganda. Ann N Y Acad Sci. 2008;1149:309-11.
14. el Sanousi SM, Omer EE. Serological survey of brucellosis in Benghazi cow project (Libya). Int J Zoonoses. 1985;12(3):207-10.

15. Aboudaya MA. An evaluation of diagnostic methods for bovine brucellosis in Libya. Int J Zoonoses. 1986;13(4):282-5.

16. Gameel SE, Mohamed SO, Mustafa AA, Azwai SM. Prevalence of camel brucellosis in Libya. Trop Anim Health Prod. 1993;25(2):91-3.

17. Tiller RV, De BK, Boshra M, Huynh LY, Van Ert MN, Wagner DM, et al. Comparison of two multiple-locus variable-number tandem-repeat analysis methods for molecular strain typing of human Brucella melitensis isolates from the Middle East. J Clin Microbiol. 2009;47(7):2226-31.

18. Alton GG, Maw J, Rogerson BA, McPherson GG. The serological diagnosis of bovine brucellosis: An evaluation of the complement fixation, serum agglutination and rose bengal tests. Aust Vet J. 1975;51(2):57-63.

19. Al Dahouk S, Tomaso H, Nockler K, Neubauer H, Frangoulidis D. Laboratory-based diagnosis of brucellosis--a review of the literature. Part II: Serological tests for brucellosis. Clin Lab. 2003;49(11-12):577-89.

20. Elarbi A. [Serological study on brucellosis in farm animals in the Yafran municipality]. Al Jabal: al Gharbi University; 1997. [In Arabic].

21. al-Khalaf SA, Mohamad BT, Nicoletti P. Control of brucellosis in Kuwait by vaccination of cattle, sheep and goats with Brucella abortus strain 19 or Brucella melitensis strain rev. 1. Trop Anim Health Prod. 1992;24(1):45-9.

22. Alton GG. Control of Brucella melitensis infection in sheep and goats--a review. Trop Anim Health Prod. 1987;19(2):65-74.

23. Gargouri N, Walke H, Belbeisi A, Hadadin A, Salah S, Ellis A et al. Estimated burden of human Salmonella, Shigella, and Brucella infections in Jordan, 2003-2004. Foodborne Pathog Dis. 2009;6(4):481-6. 